\title{
Sekuritisasi dan Kerjasama ASEAN dalam Meningkatkan Keamanan di Perairan Kawasan
}

\author{
Sukawarsini Djelantik \\ Departemen Hubungan Internasional \\ Universitas Katolik Parahyangan
}

\begin{abstract}
ABSTRAK
Sejak awal tahun 2016, kelompok teroris Abu Sayyaf yang bermarkas di Filipina Selatan meningkatkan aktivitas dengan membajak kapal-kapal berbendera Indonesia dan menyandera awaknya. Asia Tenggara dinyatakan sebagai perairan yang rawan kejahatan, sehingga kerja sama dan sekuritasi isu dalam bidang militer, politik, dan penegakan hukum perlu ditingkatkan. Tulisan ini menjawab pertanyaan: "bagaimana efektifitas upaya-upaya sekuritisasi di kawasan untuk meningkatkan keamanan di perairan Asia Tenggara? Analisis dilakukan melalui empat pendekatan yaitu pelaku sekuritisasi (securitizing actors), bentuk-bentuk ancaman nyata (existence threat), warga negara sebagai reference object dan target yang disekuritisasi (audience). Pembahasan berdasarkan berbagai upaya yang dilakukan dan kebijakan negara-negara di kawasan Asia Tenggara, dengan fokus terhadap Indonesia.
\end{abstract}

Kata kunci: terorisme, sekuritisasi, kerjasama, kawasan Asia Tenggara.

Since the beginning of 2016, terrorist group based on Phillipine, Abu Sayyaf, became more active in hijacking Indonesian-flagged ships and held the ship's crew as hostage. South East Asia region considered as dangerous maritime area which prone to hijacking activites. Therefore, this area needs more advance cooperation in military, politic, and law enforcement system in order to improve region's security. This paper answers question regarding region securitization effectiveness to improve maritime security in South East Asia. Analysis conducted by examining four factors: securitizing actors, the form of threat, state civilian, and securitization target. Discussion based on attempt of South East Asia countries to overcome security threat, focusing on Indonesia's policy.

Keywords: terrorism, securitization, cooperation, South East Asia Region 


\section{Pengantar: Kondisi Keamanan di Perairan ASEAN}

Beberapa negara di kawasan Asia Tenggara, khususnya Indonesia dan Filipina, menghadapi masalah keamanan berupa terorisme dan kekerasan oleh kelompok Islam radikal. Masalah keamanan antara lain disebabkan karakteristik kedua negara yang memiliki sejarah kekerasan politik, tingkat kemiskinan yang tinggi dan lemahnya pengawasan perbatasan antar-negara. Indonesia menjadi tempat persembunyian (safe haven) atau minimal menjadi kawasan yang aman bagi Al-Qaeda, yang sejak awal dekade 1990an telah memperkuat jaringan dengan kelompok teroris seperti Jaamah Islamiyah. (Zachary Abuza 2003, 9798). Kelompok-kelompok garis keras Islam di dua negara semakin meningkatkan radikalisasi dengan aksi-aksi lintas negara. Berbagai peristiwa pembajakan dan kriminal di Selat Malaka meningkatkan kecaman masyarakat global terhadap aksi-aksi kekerasan. Penyanderaan khususnya yang melibatkan korban warga negara Barat, dan tuntutan uang tebusan merupakan serangan terhadap kemanusiaan, selain merupakan ancaman serius bagi perdamaian dan keamanan internasional. Untuk mengatasi isu-isu keamanan, diperlukan berbagai upaya sekuritisasi, antara lain dalam bentuk kerja sama kawasan. Sekuritisasi merupakan proses yang dilakukan aktor negara untuk mentransformasi masalah keamanan, atau bentuk lain dari politisasi yang memungkinkan pemakaian cara-cara yang luar biasa demi mewujudkan rasa aman (Buzan, Wæver, de Wilde 1998, 25). Sekuritisasi berarti memberikan perhatian terhadap suatu masalah keamanan, yang diikuti oleh janji atau aksi untuk melakukan sesuatu. Ketika objek mengalami ancaman, aktor pelaku sekuritisasi memiliki hak untuk bertindak atau mernerapkan kebijakan untuk menjamin keberlangsungan hidup objek yang dilindungi (Wæver 2004, 13).

Meningkatnya aksi-aksi kekerasan di perairan Filipina oleh kelompok Abu Sayyaf, dan perompakan di Selat Malaka, menyebabkan mutlaknya kerja sama kawasan. Oleh karena keamanan kawasan Asia Tenggara berimbas signifikan terhadap kepentingan negara-negara diluar kawasan, berbagai kerjasama dengan aktor-aktor eksternal menjadi keharusan. Tulisan ini menjawab pertanyaan:"bagaimana efektifitas sekuritisasi oleh Indonesia di kawasan untuk meningkatkan keamanan di perairan Asia Tenggara?. Untuk menjawab, pembahasan ditinjau melalui empat komponen sekuritisasi, yaitu securitizing actor (pemerintah dan aparat keamanan di Indonesia), existence threat (bentuk-bentuk ancaman nyata), referent object (warga negara yang memerlukan perlindungan) dan audience (target yang disekuritisasi) (Buzan, Waever, de Wilde 1998, 25). Analisis berdasarkan berbagai upaya yang dilakukan pemerintah dan aparat keamanan Indonesia sebagai securitizing actor untuk memberi rasa aman warga negaranya (reference object). Berbagai upaya tersebut bertujuan untuk mengatasi 
ancaman keamanan maritim, khususnya di perairan Selat Malaka dan Perbatasan Filipina, dari ancaman para perompak (Selat Malaka) dan kelompok Abu Sayyaf (Perairan Filipina) sebagai pelaku kejahatan (audience). Tinjauan dibatasi pada tahun 2010-2016, dengan berdasarkan berbagai upaya mengatasi keamanan maritim secara internal dan kerjasama eksternal.

\section{Sasaran Sekuritisasi: Abu Sayyaf dan Perompak di Selat Malaka}

Target sekuritisasi pertama adalah kelompok Abu Sayyaf, yang telah melakukan berbagai aksi kekerasan di perairan Filipina. Abu Sayyaf merupakan kelompok separatis yang berpusat di Filipina Selatan, yang seringkali melakukan aksi-aksi kekerasan dan terorisme untuk mengejar tujuannya. Akibat seringnya Abu Sayyaf melakukan aksi-aksi kekerasan, menjadikan kelompok ini paling ditakuti di kawasan. Abu Sayyaf merupakan pecahan dari organisasi Front Pembebasan Nasional Bangsa Moro atau Moro National Liberation Front (MNLF), yang memisahkan diri pada tahun 1991. Perpecahan disebabkan ketidaksetujuan Abu Sayyaf menerima kesepakatan otonomi dan menuntut kemerdekaan dari Filipina dan membentuk negara Islam (Leibo 2015, 247). Aksi-aksi kekerasan antara lain pengeboman, pembunuhan, penculikan, dan pembajakan kapal-kapal laut untuk mendapatkan uang tebusan, terhadap kapal-kapal yang melintas di Perairan Filipina. Pasca revolusi di Timur Tengah yang dikenal sebagi The Arab Spring, Abu Sayyaf menjadi kelompok militan yang berafiliasi dengan Negara Islam IrakSuriah (ISIS) (Silva 2016). Afiliasi dengan organisasi yang berbeda pandangan dengan pemerintahan resmi di Filipina, menjadikan Abu Sayyaf menjadi kelompok teroris yang menjadi musuh negara.

Sepanjang tahun 2016, sudah tiga kali kelompok Abu Sayyaf menyandera pelaut-pelaut dari Indonesia, selain Malaysia, Kanada, dan Filipina. Bulan April 2016, kapal Indonesia kembali dibajak oleh dua kelompok bersenjata di Perairan Sulu, diikuti pada Bulan Mei, dan Juni 2016. Seluruh penyanderaan dilatarbelakangi motif ekonomi dengan meminta sejumlah besar uang tebusan. Setelah melalui negosiasi panjang dan pemenuhan tuntutan, para sandera berhasil dibebaskan pada 1 Mei 2016. Perairan Filipina masih merupakan ancaman serius bagi kapal-kapal asing yang melintas. Berbeda dengan pemerintah Malaysia dan Indonesia yang memenuhi tuntutan uang tebusan, pemerintah Kanada menolak pembayaran. Konsekwensinya, sandera warga negara Kanada dieksekusi kelompok Abu Sayyaf. Meskipun eksekusi telah memicu kecaman internasional, akan tetapi aksi-aksi penyanderaan terus berlanjut (East 2015, x). 
Target sekuritisasi kedua adalah perompak di perairan Selat Malaka, yang berlokasi di Perairan Sumatera dengan Semenanjung Malaka, dan menjadi pembatasan laut (sea borderlines) antara Indonesia, Malaysia, dan Singapura. Masalah keamanan di Selat Malaka termasuk perompakan, pembajakan di laut, sengketa perbatasan, dan masalah terkait kerjasama dengan militer asing. Biro Maritim Internasional (IMO) mencatat angka perompakan tertinggi terjadi di perairan Indonesia dengan 108 kasus pada tahun 2015. Posisi strategis Selat Malaka karena merupakan jalur pelayaran penting sebagai salah satu dari sembilan selat dan terusan strategis dunia, selain lintasan terdekat dari Lautan Hindia menuju Lautan Pasifik dan sebaliknya. Selat ini dilintasi 72 persen lalu lintas pedagangan internasional, dan menghubungkan Samudera Hindia dan Pasifik, atau Asia Barat ke Asia Timur. Selat Malaka membentang sekitar $800 \mathrm{~km}$ dan lebar 1,7 kilometer, setiap tahunnya rata-rata dilintasi kurang lebih 70 ribu kapal atau sekitar 150-200 kapal setiap hari. Sebagian diantaranya adalah kapal-kapal tangki raksasa yang berukuran 180.000 dwt ke atas, yang mengangkut lebih dari 40 persen produk-produk vital dunia. Volume perdagangan mencapai 19.245,7 juta ton/tahun dengan kenaikan ratarata 4,3 persen/tahun, belum termasuk petro products sebesar 15,2 juta barel/hari. Setengah dari minyak dunia diangkut melalui Selat Malaka, yang berjumlah sekitar 11 juta barel/hari, terutamanya dari Timur Tengah ke Jepang, Tiongkok dan Korea Selatan (Ong-Webb 2006, 2830). Untuk mewujudkan keamanan kawasan, Indonesia beserta negaranegara yang berbatasan langsung perlu melakukan berbagai upaya pencegahan termasuk menggalang kerjasama kawasan.

\section{Sekuritisasi Melalui Kerja sama Keamanan Internasional}

Berbagai kerjasama internasional telah dilakukan oleh Indonesia selaku securitizing actor. Jepang secara konsisten memberikan bantuan untuk membiayai Dewan Selat Malaka (The Malacca Straits Council), selain berperan membentuk The Straits of Singapore and Malacca Revolving Fund, bagi ketiga negara selat (Indonesia, Malaysia dan Singapura). Dana ini dikelola secara bergilir untuk meningkatkan keamanan melalui berbagai upaya untuk menekan angka kejahatan ke titik terendah. Kerjasama Angkatan Laut dengan Malaysia dan Filipina di wilayah utara Pulau Sulawesi menjadi acuan bagi pemerintah untuk menjamin keamanan. Indonesia berkepentingan atas keberlangsungan kerja sama mengingat peran sebagai negara kepulauan terbesar dengan wilayah perairan terluas sepanjang alur pelayaran di Selat Malaka dan Selat Singapura.

Kerja sama dan koordinasi juga ditingkatkan dengan para pengguna jasa di Indonesia, Singapura dan Malaysia. Upaya sekuritisasi dilakukan 
berupa patroli bersama Angkatan Laut Indonesia bersama Malaysia dan Filipina, meskipun masih bersifatnya bilateral. TNI Angkatan Laut (TNIAL) mengerahkan enam kapal dan satu pesawat di perairan Selat Malaka dan Laut Natuna. Indonesia sebagai salah satu pendiri Tripartite Technical Expert Group (TTEG) mengusulkan mekanisme kerja sama dan berkomitmen meneruskan kebijakan maritim jangka panjang. Terciptanya keamanan, keselamatan dan efisiensi pelayaran menghindarkan label lautan sekitar Filipina dan Indonesia menjadi "Somalia kedua". Data dari IMB menggolongkan Selat Malaka sebagai the most dangerous water yang identik dengan Pantai Somalia yang juga rawan perompakan. Kategori ini memberikan alasan kuat Amerika Serikat (AS) untuk terlibat dalam pengamanan wilayah, sekaligus menunjukkan pengaruhnya untuk menguasai secara militer. Tingginya angka kejahatan atas kapal-kapal yang melintasi Selat Malaka ini pula yang menyebabkan Singapura melibatkan AS dalam penanganan keamanan. Upaya melibatkan AS sudah dimulai sejak Maret 2010, ketika Angkatan Laut (AL) Singapura merilis informasi adanya grup teroris internasional yang merancang serangan di Selat Malaka dengan target ratusan kapal tanker yang melintas. IMB berspekulasi dengan kemungkinan kelompok teroris memiliki persenjataan berat. Meningkatnya terorisme dan perompakan di Selat Malaka merupakan salah satu alas an AS terlibat dalam pengelolaan dan pengaturan Selat (Burhansyah 2016). Opini dari AS dan negara-negara maju mengenai kondisi rawan di Selat Malaka dan perairan laut Indonesia menjadi tantangan bagi kawasan untuk menunjukkan keberhasilan mewujudkan perairan yang damai.

Kepentingan AS di kawasan Asia Tenggara menjadikannya sebagai securitizing actor eksternal. Alasan lain keterlibatan AS adalah untuk mengatasi meningkatnya perlawanan gerakan separatis seperti gerilyawan Muslim Pattani di Thailand Selatan. Untuk itu, Panglima Armada Ketujuh Pasifik AS, Laksamana Madya John M. Bird, sejak tahun 2010 telah menyampaikan keinginan menempatkan kekuatan militer, yang ditolak Indonesia. Alasan penolakan karena Indonesia hanya menerima kehadiran AS dalam format bantuan pelatihan militer dan infrastruktur persenjataan. Namun situasi keamanan yang menimpa kapal-kapal yang melintas, membuka kemungkinan muncul gugatan atau tekanan terhadap negara pantai, termasuk Indonesia, untuk bertanggung jawab terhadap keselamatan dan keamanan pelayaran. Artinya, jika ketiga negara di Selat Malaka lalai atau gagal dalam menjalankan tanggung jawab penjagaan keamanan, intervensi eksternal mendapatkan legalitasnya. Maka Indonesia dihadapkan pada pilihan; mampu melakukan perannya memberi rasa aman secara mandiri melalui kerjasama kawasan, atau melibatkan aktor eksternal. 


\section{Sekuritisasi Melalui Kerja sama Kawasan}

Dalam kasus sekuritisasi di Perairan Filipina, kerja sama kawasan diperlukan untuk memudahkan proses pengadilan, evakuasi tersangka, dan pemblokiran dana gerakan. Salah satu upaya adalah melembagakan kerja sama dalam lingkup organisasi kawasan (ASEAN), seperti yang ditetapkan dalam KTT di Cebu, Filipina sejak Januari 2007. Kerjasama regional di ASEAN meliputi kesepakatan pertukaran informasi dan merealisasikan rencana pembangunan pusat data informasi yang terhubung ke kepolisian seluruh kawasan. Sayangnya kerjasama antarpemerintah masih lemah dibandingkan organsiasi teroris yang lebih maju dalam menerapkan teknologi informasi dan komunikasi (TIK). Keberadaan internet memudahkan komunikasi, sehingga memungkinkan teroris melebarkan jaringan dan melakukan rekrutmen anggota melalui media-media sosial. Maka era globalisasi dan perkembangan teknologi informasi ini ditandai dengan keberhasilan kelompok-kelompok teroris membangun jaringan global.

Revolusi dalam TIK memaksa pemerintah mengimbangi dalam skala global untuk melawan aksi-aksi terorisme internasional. Salah satu upaya adalah memblokade sumber-sumber dana kelompok teroris. Akan tetapi efektifitas kerja sama untuk membekukan aset-aset dan mencegah pencucian uang sangat tergantung pada komitmen antar-negara. Contohnya, keberhasilan berbagai aksi penyanderaan dalam memperoleh uang tebusan menunjukkan bahwa kerja sama dan komitmen internasional masih lemah. Tidak efektifnya kerja sama disebabkan munculnya "dilema keamanan" di negara-negara demokrasi khususnya terkait isu-isu pelanggaran hak asasi manusia. Para pengambil kebijakan pada tingkat nasional perlu menempatkan keamanan bersama diatas kedaulatan negara (Enders dan Sandler 2012).

Teroris juga menyadari inefisiensi dan lemahnya kerja sama antarpemerintah, padahal ditunjang kemajuan TIK dan transportasi. Selain itu, terdapat efek negatif pencegahan terorisme internasional, misalnya ketika dilakukan aksi proaktif untuk melindungi kepentingan negaranegara lain, justru menyebabkan kemarahan teroris dan pendukungpendukungnya. Respons proaktif ini biasanya memotivasi serangan teroris yang lebih hebat di kemudian hari. Serangan biasanya diarahkan kepada target yang lemah di luar negara yang melakukan tindakan proaktif tersebut (Enders dan Sandler 2012).

Kerja sama regional juga perlu memperhatikan perbedaan kondisi dan situasi antara teroris dan pemerintah. Kelompok-kelompok teroris modern cenderung bekerja sama dalam jaringan yang longgar dan dalam sel-sel yang saling tidak mengenal. Jaringan terorisme konvensional bekerja dalam tingkatan yang berbeda-beda, misalnya 
dalam kegiatan pelatihan, intelijen, menyediakan safe haven, dukungan finansial, bantuan logistik, perolehan senjata, dan pertukaran personil. Dilain pihak, kerja sama antar negara dalam melawan terorisme terbatas karena mempertimbangkan masalah otonomi dan kedaulatan. Peristiwa pembajakan dan penyanderaan menuntut partisipasi global dalam berbagai kapasitas untuk penanggulangan dikemudian hari (Djelantik 2010, 213-215)

Permasalahan lain terkait perbedaan jangka waktu antara pemerintah dengan teroris. Di negara demokrasi liberal, kepentingan politis pejabat pemerintah dijabarkan melalui pemilihan umum berikutnya dan kemungkinan terpilih kembali. Pejabat yang hanya memiliki sisa satu periode kepemimpinan lagi, tidak akan terlalu memperdulikan konsekuensi keputusan yang diambil terhadap hasil pemilu berikutnya. Karena pemerintah berganti, kesepakatan dengan teroris yang ditandatangani dengan Presiden sebelumnya kemungkinan tidak terpakai lagi (Enders dan Sandler 2012, 170). Faktor-faktor diatas menunjukkan kemampuan teroris yang lebih besar daripada pemerintah dalam menghargai kepentingan bersama dengan cara mensinergikan tujuan.

Melalui jaringan globalnya, teroris dapat mengidentifikasikan target yang lemah selain memakai sel terbaik yang dimiliki untuk menjangkau target operasi (Enders dan Sandler 2012, 779-802). Ketidakseimbangan ini merupakan keuntungan bagi teroris, karena pemerintah dan rakyat menjadi sasaran yang empuk, sementara teroris dan tempat persembunyiannya tetap menjadi target yang sulit. Teroris seringkali bersembunyi diantara penduduk biasa di kota-kota besar, atau di pedalaman hutan yang sulit dijangkau. Pemerintah akan mengalami kerusakan yang lebih besar jika melakukan operasi di tengah kota. Maka pemerintah harus melakukan penjagaan di sebanyak mungkin tempat, sementara teroris dapat mengidentifikasikan dan mengarahkan target ke sasaran-sasaran yang lemah. Hal ini berarti bahwa penjagaan oleh pemerintah berbiaya relatif mahal karena harus beruntung setiap hari agar tidak menjadi korban. Dalam hal ini, teroris dapat menunggu dan memilih waktu yang paling tepat untuk beraksi. Pemerintahan yang demokratis memiliki berbagai keterbatasan dalam merespons teroris, sementara teroris fundamentalis tidak memiliki batasan untuk melakukan aksi sebrutal apapun. Pemerintah juga memiliki jenjang hirarki, sementara organisasi teroris lebih fleksibel (Ender dan Sandler, 2003).

Oleh karena organisasi teroris yang tidak terstruktur secara tegas, sel-sel dan kelompok-kelompok teroris dapat beroperasi sendiri-sendiri. Penyusup dan mata-mata dapat menyebabkan kehancuran jika struktur pemerintah terbongkar. Kebalikannya, teroris yang tertangkap hanya 
dapat memberikan sedikit informasi intelijen mengenai otonomi dan komponen-komponen jaringannya. Banyaknya sasaran yang perlu dilindungi merupakan kerugian bagi pemerintah, karena berarti memerlukan koordinasi yang lebih solid. Sementara itu, jaringan sel teroris yang tidak terlalu kaku menjadikan jumlah yang besar sebagai keuntungan karena berarti lebih banyak sumber daya yang dapat dipakai.

Ketidakseimbangan lain terdapat dalam informasi; pemerintah tidak terinformasi mengenai kekuatan teroris, kebalikannya teroris dengan mudah menemukan jenis dan jumlah program anti-teror pemerintah. Di beberapa negara demokrasi liberal, informasi-informasi program pemerintah bahkan dapat diakses dengan mudah selain diumumkan kepada publik. Ketidakseimbangan ini tercermin dengan jelas dalam laporan pemerintah AS yang menyatakan jumlah anggota Abu Sayyaf kira-kira 400 orang (US National Security, 2016). Dengan banyaknya kendala diatas, aktor-aktor sekuritisasi memerlukan strategi yang lebih canggih dan informasi yang lebih akurat daripada yang dimiliki kelompok teroris. Pada era globalisasi dan kecanggihan informasi, pemerintah perlu meningkatkan kapasitas teknologi agar tidak tertinggal dari kelompok teroris. Pemerintah dituntut untuk mengoptimalkan program-program kerja sama kawasan dan dalam skala global.

\section{Bentuk-bentuk Kerjasama Dalam Lingkup ASEAN}

Meskipun ASEAN sudah berdiri sejak 1967, kerja sama kawasan mulai berlangsung sejak era 1990an ketika terorisme menjadi isu global. Pada konferensi yang diikuti oleh Menteri-menteri Dalam Negeri ASEAN mengenai masalah-masalah kejahatan transnasional tahun 1997, dibahas kerjasama pemberantasan terorisme yang salah satunya berupa tukar menukar informasi dan koordinasi. Rincian dokumen termasuk memperkuat komitmen negara anggota untuk berpartisipasi dalam memberantas kejahatan regional. Kerjasama juga ditunjukkan dalam bentuk menyelenggarakan pertemuan para menteri ASEAN mengenai kejahatan lintas negara dan penandatanganan kesepakatan untuk memberikan bantuan hukum dan menandatangani traktat dan nota kesepahaman (MoU) (Sekretariat ASEAN 2007). ASEAN dan organisasiorganisasi lainnya yang lebih besar, seperti ASEAN Regional Forum (ARF) dan Asia-Pacific Economic Coperation (APEC), telah melakukan berbagai inisiatif, termasuk membangun mekanisme berbagi informasi data intelijen dan praktek-praktek terbaik. Pemerintah juga bersepakat dalam menerapkan penegakan hukum dan kemampuan investigasi lembaga-lembaga di setiap anggota (Sekretariat ASEAN 2007). 
Kerja sama keamanan ASEAN dilakukan melalui penerapan kebijakan yang efektif dan strategis untuk meningkatkan kesejahteraan rakyat. Semua konvensi internasional terkait terorisme harus ditandatangani dan diratifikasi, misalnya "mekanisme ASEAN dalam melawan terorisme". ASEAN bersepakat meningkatkan tukar menukar informasi dan kerjasama antar-lembaga terkait pencegahan terorisme. ASEAN mendukung pemberantasan terorisme melalui kerjasama pendeteksian, investigasi, monitoring, dan pelaporan. Peran ASEAN dilakukan dengan cara meningkatkan koordinasi internasional seperti yang terjadi pada tahun 1999, dengan mengeluarkan rencana aksi pemberantasan aksiaksi kejahatan lintas negara pada level nasional, regional dan global. Indonesia menjalankan kebijakan yang lebih sistematis dengan membangun kerjasama kawasan, selain berpartisipasi dalam Pertemuan Tingkat Tinggi (ASEAN Declaration on Joint Action to Counter Terrorism) pada bulan November 2001 di Brunei Darussalam. Pertemuan ini telah mengadopsi deklarasi ASEAN tahun 2001 mengenai aksi bersama anti terorisme.

Upaya lain ASEAN adalah membentuk jaringan diantara badan-badan penegakan hukum terkait pemberantasan terorisme dan saling tukar menukar data intelijen. ASEAN juga menjalankan beberapa pelatihan perang urat syaraf bagi para petugas kepolisian dan intelijen, cara mendeteksi bahan-bahan peledak (bom), dan investigasi pasca ledakan. Pelatihan juga diberikan mengenai keamanan di bandara dan keamanan dokumen perjalanan, termasuk masalah-masalah imigrasi dan pengawasan perbatasan. Salah satu pelatihan pada awal tahun 2004 dilakukan atas bantuan dan kerjasama dari pemerintah Australia. Lebih lanjut, ASEAN juga mengadopsi konvensi untuk pemberantasan terorisme dalam ASEAN Security Community Plan of Action sehingga kerjasama berkekuatan hukum (Ong Keng Yong 2001).

Meningkatnya peristiwa penyanderaan di perairan kawasan merubah fokus kerja sama ASEAN. Negara-negara di kawasan mengeluarkan deklarasi bersama dalam program-program anti-pembajakan di lautan, selain membangun kerangka kerja sama keamanan yang lebih luas. Kerja sama dimulai dengan pertemuan Menteri Dalam Negeri, diikuti penandatanganan dekalarasi ASEAN untuk Aksi-aksi kejahatan lintas negara (ASEAN Declaration on Trasnorganized Crime) atau AMMTC. Organisasi ini diberi mandat untuk berkoordinasikan dengan badanbadan seperti organisasi para Menteri Hukum dan Kejaksaan Agung, Kepala Kepolisian, Menteri Keuangan, Direktur Jenderal Imigrasi dan Bea dan Cukai, untuk keperluan investigasi, pemeriksaan dan rehabilitasi pelaku kejahatan lintas negara, termasuk terorisme internasional (Ong Keng Yong 2001). 
ASEAN juga melakukan kerja sama lintas kawasan dengan Uni Eropa dengan memasukkan isu terorisme ke dalam agenda pembahasan ARF. Kerja sama dititikberatkan pada penegakan hukum, pelatihan agen-agen inetelijen, menekan sumber-sumber keuangan teroris, memperkuat keamanan di perbatasan termasuk perpindahan penduduk, barang dan dokumen. Peningkatan keamanan dilakukan guna meminimalisir penyelundupan barang melalui jalur pipa dan pembajakan laut. ASEAN juga menyelenggarakan Inter-sessional Meeting on Counter-terrorism and Transnational Crime (ISM-CTTC) dalam kerangka ARF. Selain itu, dipromosikan pula kerja sama antar-negara dan praktek-paraktek terbaik dalam mempromosikan keamanan perjalanan di darat, kereta, udara, laut dan transportasi multi moda. ISM-CTTC memonitor dan mendukung partisipasi ARF dalam hukum internasional melalui pemberian arahan untuk keselamatan dalam organisasi penerbangan sipil (International Civil Aviation Organization (ICAO)) untuk meningkatkan keamanan di udara. ASEAN juga mempertegas konvensi aksi-aksi kejahatan yang melanggar keamanan lalu lintas di laut (diantara negara-negara ASEAN, Brunei Darussalam, Myanmar, Filipina, Singapura dan Vietnam). Penandatangan termasuk kerja sama hukum pada Organisasi Kelautan Internasional (International Maritime Organization's (IMO), International Ship and Port Facility Security/ISPS (Ong Keng Yong 2001).

ASEAN lebih lanjut membahas kesepakatan anti-teror dengan Australia pada bulan Juni 2004, berupa pencegahan ancaman kejahatan transnasional dan meningkatkan keamanan non-tradisional. Deklarasi ASEAN-Australia menyepakati peningkatkan kerja sama dengan lembaga-lembaga penegak hukum dan keamanan. Kerja sama juga terjadi dalam tukar menukar informasi intelijen, data keuangan kelompok-kelompok teroris dan kejahatan pencucian uang. Kerja sama diperluas dengan Tiongkok pada November 2002, Uni Eropa (Januari 2003), India (Oktober 2003), Jepang (November 2004), Federasi Rusia (Juni 2004), dan Amerika Serikat (Agustus 2002) yang difokuskan pada keamanan transportasi dan pengawasan di perbatasan negara. Kerja sama juga disepakati setelah pertemuan para menteri untuk mengatasi kejahatan transnasional antara ASEAN dengan tiga negara lainnya dalam kerangka ASEAN +3 (Tiongkok, Jepang dan Korea Selatan) sejak bulan Januari 2004 (Ong Keng Yong 2001). Meskipun sudah mencakup hampir semua aspek keamanan internasional, termasuk transportasi dan keamanan di lautan, akan tetapi kerja sama masih lemah dalam implementasi kebijakan. Selain itu, belum ada mekanisme hukum terhadap pelanggaran-pelanggaran kesepakatan. Maka kerja sama baru berupa kebijakan formal tanpa implementasi terarah. Dibawah ini akan dibahas berbagai kelemahan dalam implementasi kebijakan, terkait sensitivitas kedaulatan, perbedaan kondisi dan kebijakan negara-negara 
anggota. Pembahasan lainnya adalah tentang perbedaan cara pandang dan kepentingan mengenai peran Amerika Serikat di kawasan.

Pertama adalah persoalan sensitivitas kedaulatan. Masalah kedaulatan menyebabkan beberapa negara, seperti Indonesia dan Malaysia, enggan menerima keberadaan kekuatan asing di sekitar perairan kawasan untuk kepentingan operasi anti-terorisme. Kedua negara memprotes usulan "Inisiatif AS Mengenai Keamanan Maritim Kawasan" (Regional Maritime Security Initiative (RMSI), untuk mengamankan perairan Asia Tenggara dari pembajakan laut dan terorisme. Bahkan kelompok ektremis domestik seperti MMI (Majelis Mujahidin Indonesia), mengusulkan untuk mendukung tentara Indonesia mengusir armada AS jika berada di Selat Malaka. Kekhawatiran terkait isu bahwa operasi AS untuk menekan aksi-aksi terorisme akan dieksploitasi oleh kelompokkelompok militan untuk memobilisasi dukungan dan mendiskreditkan pemerintah. ASEAN mengharapkan bahwa bentuk-bentuk bantuan AS melalui aksi-aksi militer langsung dikurangi dan lebih banyak berupa inisiatif untuk memenangkan hati dan pikiran masyarakat (Burmansyah 2016).

Persoalan kedua meliputi perbedaan kebijakan dan kondisi negara Anggota. Kelemahan kedua terjadi pada level kawasan, ketika negaranegara anggota menerapkan strategi dan kebijakan yang berbeda-beda. Perbedaan nyata tampak dalam menanggapi kebijakan AS, misalnya Singapura dan Filipina yang mendukung keberadaan militer eksternal, sementara Malaysia dan Indonesia menolak. Usaha lain AS adalah menawarkan Indonesia untuk bergabung dalam Inisiatif Keamanan Proliferasi (Proliferation Security Initistive/PSI). Penolakan Indonesia berdasarkan pertimbangan keberadaan Indonesia sebagai negara yang berdaulat. Persetujuan berarti mengizinkan AS memeriksa kapal laut manapun di lautan lepas termasuk Selat Malaka. Kelemahan ketiga terkait perbedaan karakteristik dan kondisi dalam negeri masing-masing negara yang menghasilkan respons berbeda-beda. Contohnya kondisi politik dalam negeri di Indonesia pasca reformasi menghasilkan aksi sekuritisasi yang "agak tegas", sementara Singapura menerapkan kebijakan yang "lebih tegas" (Febrica 2012). Dukungan AS di Asia Tenggara ditunjukkan melalui dukungan keuangan dan memasukkan kawasan sebagai "front kedua" dalam melawan terorisme"(Febrica 2012, 572). Posisi sebagai "front kedua" menunjukkan seolah-olah negaranegara di kawasan bersikap bersahabat terhadap terorisme. Sekuritisasi diberikan melalui dukungan keuangan AS kepada Filipina sejumlah USD 100 juta, untuk pelatihan, peralatan militer, dan mempertahankan dukungan bagi Angkatan Bersenjata Filipina. Tahun 2002, sejumlah 660 tentara khusus AS diterjunkan di Filipina Selatan untuk memberantas kelompok Abu Sayyaf. Amerika Serikat dan Filipina memberi label pada 
operasi militer di Mindanao sebagai "latihan untuk membela konstutusi Filipina yang melawan keberadaan tentara asing”.

Ketiga adalah peran Amerika Serikat di kawasan.Negara-negara di kawasan memiliki cara pandang berbeda mengenai peran AS. Singapura telah meningkatan hubungan dengan AS melalui penandatanganan kesepakatan strategis antara Perdana Menteri Lee Hsien Loong dan Presiden Bush pada bulan Juli 2005. Berbeda dengan Indonesia dan Malaysia yang menolak kerja sama formal, Singapura telah menandatangani kerjasama bidang militer, teknologi dan perumusan kebijakan. Dalam wawancara dengan televisi Cable News Network (CNN), Lee Kuan Yew mengklaim bahwa Singapura akan mengalami risiko penyerangan teroris sepanjang para pemimpin ekstrimis masih bebas berkeliaran di Indonesia. Lee Kuan Yew lebih jauh mengklaim bahwa Indonesia enggan menindak para pelaku atau yang dicurigai sebagai teroris.

\section{Sekuritisasi Melalui Pernyataan (Speech Act)}

Selain melalui tindakan nyata, upaya sekuritisasi dapat dinilai melalui berbagai pernyataan terkait isu keamanan dari para pemimpin di kawasan. Berbagai masalah keamanan yang masih berlanjut termasuk perompakan, penyanderaan, penyelundupan manusia dan obat-obatan terlarang, menunjukkan instabilitas kawasan. Mantan Presiden Indonesia Megawati (2000-2004) menyatakan bahwa tidak ada satu negarapun atau sekelompok negara yang dapat menanggulangi ancaman terhadap teroris internasional seorang diri. Maka peningkatan kerja sama internasional dalam menanggulangi masalah keamanan di kawasan sudah menjadi fokus kebijakan Indonesia. Komitmen Indonesia berlanjut pada masa pemerintahan Presiden Soesilo Bambang Yudhoyono (SBY). Dalam penerapannya, Presiden SBY berupaya menyeimbangkan antara kebijakan menghancurkan jaringan teroris yang berbasis agama melalui kerja sama dengan masyarakat internasional disatu pihak, dan dipihak lain tidak menentang keinginan partai-partai Islam pendukung pemerintah. Kebijakan SBY diimplementasikan oleh Menteri Luar Negeri Indonesia, Marty Natalegawa, yang menyatakan bahwa mengatasi akar masalah merupakan solusi mendasar untuk mengatasi terorisme, radikalisme dan ekstrimisme. Untuk itu diperlukan sinergi kebijakan pada tingkat nasional, regional dan global, serta membangun kondisi kondusif untuk menghambat perkembangannya. Sambil menerapkan sistem yang pluralistik, Indonesia tetap menghadapi perlawanan langsung melalui opini publik di dalam negeri. Kedua hal ini menjadi fokus dan rencana kerja dalam Forum Global Kerjasama Anti-Terorisme atau Global Counterterrorism Forum (GCTF). Selanjutnya Menlu natalegawa juga 
berkomitmen melanjutkan kerja sama dengan AS dalam penyelidikan dan penindakan.

Era Presiden Jokowi, Indonesia lebih banyak menghadapi permasalahan keamanan di perairan ASEAN. Penculikan, penyanderaan, dan perompakan oleh kelompok bersenjata di wilayah laut Indonesia, Malaysia, dan Filipina semakin tinggi, seiring dengan potensi ekonomi dan perdagangan yang besar di ketiga negara. Presiden Jokowi menegaskan kerjasama negara-negara ASEAN untuk menjaga keamanan kapal-kapal yang melintas di perairan perbatasan dan sekitarnya. Berulangnya penyanderaan dan perompakan terhadap warga negara Indonesia yang melintas di Perairan Filipina juga sebagai akibat dipenuhinya tuntutan pembayaran uang tebusan. Maka sebagai upaya meningkatkan kerjasama di kawasan adalah dikeluarkannya kesepakatan antar Menteri Luar Negeri dan Panglima Militer dari Indonesia, Malaysia dan Filipina pada Mei 2016. Empat hal penting yang disetujui terkait patroli bersama, tindakan-tindakan dalam menghadapi penyanderaan, dan tukar-menukar informasi. Disepakati juga usulan Indonesia untuk membuka hotline antara crisis center Indonesia-Flipina-Malaysia dan penyusunan Prosedur Standar Operasional (SOP) oleh Panglima tiga negara.

Pernyataan dari Menteri Luar Negeri Indonesia Retno Marsudi untuk menghindarkan berulangnya peristiwa penyanderaan, adalah menegaskan kepada pemerintah Filipina agar lebih serius menjaga wilayah perairannya. Indonesia menyadari bahwa kelompok Abu Sayyaf yang berbasis di Filipina tidak dapat ditangani oleh negara lain kecuali Filipina sendiri. Sebagai masalah domestik yang menyangkut warga negara lain, kerjasama kawasan tidak dapat menjangkau kelompok ini kecuali atas permintaan pemerintah Filipina. Hal maksimal yang dapat dilakukan Indonesia adalah meningkatkan kerjasama dengan Pemerintah Filipina dalam menjaga perairan di perbatasan yang rawan kejahatan. Pada level ASEAN, Forum ASEAN Foreign Minister's Meeting (AMM) ke-49 di Laos pada 23-26 Juli 2016, telah membahas isu keamanan laut di kawasan. Mengenai upaya pembebasan sandera melalui pembayaran uang tebusan, anggota parlemen Indonesia menuntut agar pemerintah tidak membayar uang tebusan, agar tidak menjadi preseden buruk. Akan tetapi mengingat itu merupakan satusatunya jalan untuk memberikan perlindungan terhadap warga negara, pembayaran uang tebusan telah dilakukan. Akan tetapi, Filipina juga dituntut dapat menyelesaikan masalah internalnya terkait keberadaan Abu Sayyaf dan kelompok lain yang merugikan negara tetangga. Pernyataan-pernyataan para pemimpin diatas juga diperkuat dengan tindakan-tindakan nyata dan mengupayakan upaya kerja sama yang lebih erat. Walaupun demikian, kerja sama yang berlangsung belum 
berjalan efektif, terbukti dengan masih berlangsungnya aksi-aksi terorisme dan kriminal di Perairan Filipina maupun Selat Malaka.

\section{Simpulan}

Isu keamanan maritim telah menjadi tantangan bagi Indonesia, selain menguji kemampuan ASEAN sebagai organisasi kerja sama kawasan. Sebagai negara yang memiliki wilayah perairan terluas, Indonesia telah melakukan berbagai upaya sekuritisasi untuk mengatasi masalahmasalah keamanan termasuk pemberantasan terorisme. Kerja sama dalam organisasi kawasan yang telah menghasilkan berbagai kebijakan, termasuk penerapan undang-undang anti-terorisme dan bekerja sama aktif dalam berbagai inisiatif global. Kesadaran mengenai pentingnya kerja sama dalam mewujudkan keamanan kawasan ditunjukkan melalui peningkatan upaya-upaya sekuritisasi kawasan. Sejauh ini, sekuritisasi baru terbatas dalam bidang-bidang kerja sama pemberantasan, dan kurang dalam program-program pencegahan. Masyarakat umum belum banyak dilibatkan misalnya melalui program-program pendidikan, sosial dan budaya pada level kawasan.

Untuk mengatasi masalah-masalah terorisme dan aksi-aksi kriminal, kerja sama kawasan baik bilateral maupun multilateral perlu ditingkatkan. Sejauh ini telah dilaksanakan berbagai pertemuan antar para pemimpin negara yang melahirkan berbagai kebijakan dan produkproduk hukum, namun masih lemah dalam implementasi. Belum efektifnya kerja sama antara lain disebabkan masalah sensitivitas kedaulatan, kebijakan serta kondisi negara yang berbeda, dan perbedaan dalam melihat peran AS. Negara-negara anggota ASEAN belum menyepakati mekanisme kerja sama, selain belum tegasnya penegakan hukum terhadap para pelaku kejahatan. Bahkan dalam kasus di Indonesia, masih terjadi kelemahan koordinasi antara lembaga-lembaga yang berwenang seperti kementrian Luar Negeri, TNI dan BIN. Contohnya, terkait patroli bersama di wilayah perairan yang disepakati antara Indonesia, Filipina, dan Malaysia, yang sampai saat ini ketiga pihak masih membahas Prosedur Standar Operational (PSO).

Selain masalah teknis, kerja sama bilateral yang sudah berlangsung belum berjalan efektif, misalnya antara Indonesia-Malaysia, dan Indonesia-Filipina. Kelemahan lainnya adalah belum berjalannya tindak lanjut nota kesepahaman (MoU) trilateral antara Indonesia, Malaysia dan Filipina, mengenai konsep strategis, operasional dan teknis. Upaya bilateral dan trilateral perlu diperkuat dengan mekanisme kerjasama multilateral diantara negara-negara di kawasan, agar Selat Malaka dan perairan sekitar Filipina tidak menjadi "Somalia di Asia tenggara". Tidak kalah pentingnya perlunya "efek gentar" dari kerja sama kawasan, untuk memberi efek jera bagi para perompak dan penyandera seperti 
kelompok Abu Sayyaf. Indonesia dan negara-negara di ASEAN perlu menunjukkan kepada masyarakat global kemampuan untuk mengatasi masalah-masalah keamanan, tanpa campur tangan eksternal. Negara yang memiliki kewenangan, persenjataan, otoritas, dan legalitas yang kuat, tidak boleh kalah oleh kelompok teroris maupun kriminal. Rasa aman perlu dapat dinikmati oleh seluruh warga negara kawasan, yang merupakan tanggungjawab pemrintah beserta aparat keamanan untuk mewujudkan.

\section{Daftar Pustaka}

\section{Buku dan Jurnal}

Abuza, Zachary, 2003, Militant Islam in Southeast Asia, Crucible of Terror, Lynne Rienner Publisher, USA.

Buzan, Barry, Ole Wæver, and Jaap de Wilde, 1998, Security: A New Framework for Analysis, Boulder: Lynne Rienner Publishers.

Djelantik Sukawarsini, 2010, Terorisme: Tinjauan Psikopolitis, Peran Media, Kemiskinan, dan Keamanan Nasional, Yayasan Obor Indonesia, Jakarta.

Cassman, Daniel, 2015, "Moro National Liberation Front". Mapping Militant Organizations, Stanford University Press.

Dosch, Joern, 2003, Relations between the European Union and ASEAN, European East Asian Studies, Vol 22.

Enders, Walter dan Todd Sandler, 2012, The Political Economy of Terrorism (Edisi ke 2), Cambridge University Press, NY.

East, Bob, 2015, 472 Days Captive of the Abu Sayyaf: The Survival of Australian Warren Rodwell, Cambridge Scholars Publishing.

Febrica, Senia, 2010, Securitizing Terrorism in Southeast Asia, Accounting for the Varying Responses of Singapore and Indonesia, Asian Survey Vol. 50 No. 3.

Leibo, Steven A, 2016, East and Southeast Asia, The World Today Series 2015-2016, 48 ${ }^{\text {th }}$ Edition, Rowman \& Littlefiled.

Ong-Webb, 2006, Graham Gerard, Piracy, Maritime Terrorism and Securing the Malacca Straits, International Institute of Asian Studies (IIAS), Leiden.

Pahl, Nadine, Anne Richter, 2007, Scholarly Research paper, Swot Analysis - Idea, Methodology and a Practical Approach, Grin Verlag.

Sandler, Todd, 2003, Collective Action and Transnational Terrorism, World Economy, 26 (6).

Seniwati, Mohd. Azizuddin Mohd Sani, K. Nadaraja, Cooperation between Indonesia and ASEAN to counter terrorism in Indonesia, Academic Research International, Januari 2012. 
Wæver, Ole, 2004, "New Schools in Security Theory and the Origins between Core and Periphery', Montreal: ISA Conference, March.

\section{Media Massa}

Eddy Burhamsyah, 2016, Indoprogress, Internasionalisasi Selat Malaka, http://indoprogress.com/2016/o6/internasionalisasi-selatmalaka/

Langkah Encep Berakhir di Kota Candi, Majalah Gatra, http://www.gatra.com/2003-0822/versi_cetak.php?id=30748.

Indonesia Changing Face of Terrorism, The Jakarta Globe, http://www.thejakartaglobe.com/home/indonesiaschanging-face-of- terrorism/436807.

Cable News Network http://www.cnn.com/2002/WORLD/asiapcf/southeast/10/13/b ali.blast/

"KTT Ke-12 ASEAN Hasilkan Empat Deklarasi”, Harian Media Indonesia, Minggu 14 Januari 2007.

"ASEAN Segera Bangun Pusat Data Terorisme”, Harian Media Indonesia, 15 Januari 2007.

Desi U. Fabiola, 2010, Indonesia Signs UN Convention on Terrorism, The Jakarta Post, 26 September.

Dillon, B, 2003. Terrorists Hambali Tells All. Sunday Times, 12 Oktober.

New Age International, 2002.

The Jakarta Post 2003.

\section{Sumber Internet}

http://www.gosumbar.com/berita/baca/2016/o6/24/dpr-mintafilipina-perkuat-keamanan-perairan-agar-kasus-penyanderaantak-terulang-lagi\#sthash.py6Ny96R.dpuf

Council on Foreign Relations, 2008, Jemaah Islamiyah, http://www.cfr.org/indonesia/jemaah-islamiyah-k-jemaahislamiah/p8948.

Department of State, The Global War on Terrorism, the First 100 Days, lihat di: http://2001-009.state.gov/s/ct/rls/wh/6947.htm.

Department of State, Background Briefing: Senior State Department Official on Global Counterterrorism Forum in Istanbul, http://www.state.gov/r/pa/prs/ps/2012/o6/191924.htm

Defence Casualty Analysis System (DCAS): https://www.dmdc.osd.mil/dcas/pages/casualties_gwt_combine d.xhtml 
Non-Traditional Security Threats in Southeast Asia, Policy Bulletin, The Stanley Foundation, 16-18 Oktober 2003.

International Crisis Group, 2003, Jemaah Islamiyah in South East Asia: Damaged but still Dangerous, Asia Report No 63, 26 Agustus 2003 , Jakarta. http://www.icg.org/home/index.cfm?id=1452\&1=5.

Global Security: http://www.globalsecurity.org/security/ops/bali.htm.

Laporan Komisi 11/9, Laporan Akhir Komisi Nasional Mengenai Serangan Teroris terhadap AS, edisi resmi pemerintah: http://www.gpoaccess.gov/911/index.html.

Sekretariat ASEAN, 2007, ASEAN Convention on Counter Terrorism. Bandar Seri Begawan, 5 November, https://www.aseansec.org/19250.htm.

Ong Keng Yong, ASEAN'S Contribution to Regional Efforts in CounterTerrorism, http://www.aseansec.org/17274.htm.

http://jaringnews.com/internasional/asia/22080/hillary-clinton-lebihbanyak-bahas-terorisme- ketimbang-toleransi-beragama.

http://nasional.kompas.com/read/2016/o6/24/18035981/hindari.peny anderaan.berulang.fadli.zon.minta.pemerintah.beri.peringatan. $k$ husus?utm_campaign=related\&utm_medium $=b p \& u t m \_s o u r c e=$ news\&

http://www.revolvy.com/main/index.php?s=Moro\%20National\%20Lib eration\%20Front\&item_type=topic

BBC News, http://www.bbc.com/news/world-asia-36138554,.

Cristina Silva, http://www.ibtimes.com/what-abu-sayyaf-isissupporters-philippines-threaten-behead-canadian-hostagesjohn-2359187

Philippines unrest: Who are the Abu Sayyaf group? http://www.bbc.com/news/world-asia-36138554,

Edy Burmansyah, http://indoprogress.com/2016/o6/internasionalisasiselat-malaka/

https://www.nationalsecurity.gov.au/Listedterroristorganisation s/Pages/AbuSayyafGroup.asp

Tanpa Nama, thesis Universitas Muhammadiyah Yogyakarta, "Sensitifitas Indonesia terhadap keterlibatan Amerika Serikat dalam Mengatasi Kejahatan di Selat Malaka", http://thesis.umy.ac.id/datapublik/t11810.pdf.

http://news.detik.com/berita/3201064/ini-pernyataan-lengkappresiden-jokowi-soal-pembebasan-10-sandera-abu-sayyaf,.

http://setkab.go.id/bahas-keamanan-perairan-perbatasan-presidenjokowi-terima-menlu-dan-panglima-filipina-dan-malaysia/,.

http://nasional.kompas.com/read/2016/o6/24/16291961/indonesia.ma laysia.dan.filipina.diminta.implementasikan.kesepakatan,.

http://www.gosumbar.com/berita/baca/2016/o6/24/dpr-mintafilipina-perkuat-keamanan-perairan-agar-kasus-penyanderaantak-terulang-lagi\#sthash.py6Ny96R.dpbs 
http://www.antaranews.com/berita/569496/indonesia-minta-filipinapastikan-keamanan-perairan

https://m.tempo.co/read/news/2016/o7/22/078789608/banyakpenyanderaan-asean-akan-bahas-keamanan-laut-filipina 